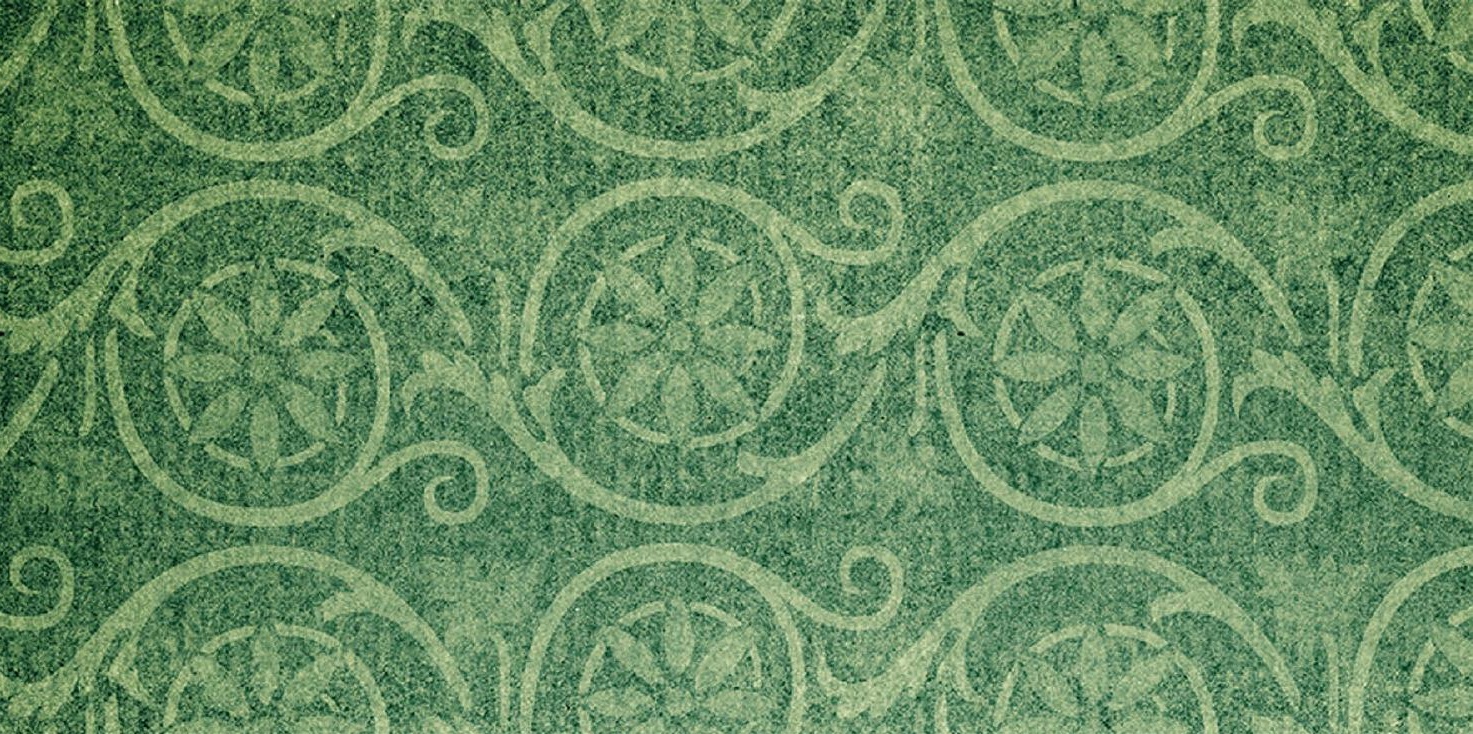

\title{
THE PHILOSOPHICAL MYSTICISM OF GERARD MANLEY HOPKINS
}

Aakanksha Virkar Yates 


\section{The Philosophical Mysticism of Gerard Manley Hopkins}

Through the lens of Hopkins's 'masterwork', The Philosophical Mysticism of Gerard Manley Hopkins readdresses Hopkins's frequently overlooked mysticism as an interior narrative within his corpus. Drawing on a range of religious, literary and visual traditions from Augustine's Confessions to the seventeenth-century spiritual emblem, this book demonstrates the ways in which the Wreck deliberately constructs and conceals a mystical and contemplative narrative. Typology and allegory are some of the important hermeneutic tools used in this re-rereading of Hopkins, relating the poet to the discursive tradition surrounding the Old Testament Song of Songs, the philosophical theology of the Greek Fathers and, perhaps most intriguingly, the meditative and visual tradition of the baroque heart-emblem. On the centenary of the publication of Hopkins's poems, this book places the writer firmly within a mystical tradition, necessitating a fundamental reconsideration of the legacy of this major Victorian poet.

Aakanksha Virkar Yates is a Lecturer in English literature at the University of Brighton, specialising in nineteenth century and modern literature. Her research is fundamentally interdisciplinary, placing literary works in dialogue with theology, philosophy, visual culture and music. Working in the growing field of inter-art studies, Dr. Virkar Yates is also the recipient of several awards, from the Nehru Trust for Cambridge University, the J. N. Tata Fund and recently a Rising Stars award from the University of Brighton. 


\section{The Nineteenth Century Series}

Series editor: Joanne Shattock

Professor Emeritus, University of Leicester, UK

The series focuses primarily upon major authors and subjects within Romantic and Victorian literature. It also includes studies of other nineteenth-century British writers and issues, where these are matters of current debate: for example, biography and autobiography; journalism; periodical literature; travel writing; book production; gender; noncanonical writing.

Recent in this series:

Life Writing and Victorian Culture

Edited by David Amigoni

Pre-Raphaelite Masculinities

Edited by Amelia Yeates and Serena Trowbridge

Thackeray in Time

History, Memory and Modernity

Edited by Richard Salmon and Alice Crossley

The Philosophical Mysticism of Gerard Manley Hopkins

Aakanksha Virkar Yates 


\title{
The Philosophical \\ Mysticism of Gerard \\ Manley Hopkins
}

\author{
Aakanksha Virkar Yates
}

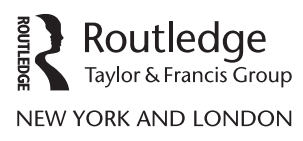


First published 2018

by Routledge

711 Third Avenue, New York, NY 10017

and by Routledge

2 Park Square, Milton Park, Abingdon, Oxon OX14 4RN

Routledge is an imprint of the Taylor \& Francis Group, an informa business

(C) 2018 Taylor \& Francis

The right of Aakanksha Virkar Yates to be identified as author of this work has been asserted by her in accordance with sections 77 and 78 of the Copyright, Designs and Patents Act 1988 .

All rights reserved. No part of this book may be reprinted or reproduced or utilised in any form or by any electronic, mechanical, or other means, now known or hereafter invented, including photocopying and recording, or in any information storage or retrieval system, without permission in writing from the publishers.

Trademark notice: Product or corporate names may be trademarks or registered trademarks, and are used only for identification and explanation without intent to infringe.

Library of Congress Cataloging-in-Publication Data

CIP data has been applied for.

ISBN: 978-1-138-09390-4 (hbk)

ISBN: 978-0-429-50627-7 (ebk)

Typeset in Sabon

by codeMantra 
For Elizabeth, Thea and Elias 


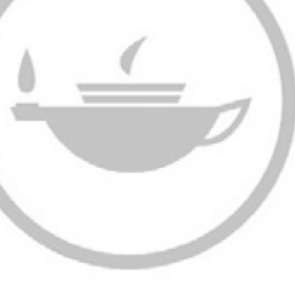

Taylor \& Francis
Taylor \& Francis Group http://taylorandfrancis.com 


\section{Contents}

Acknowledgments $\quad$ ix

1 'Rare-Dear Gerard': Hopkins and the Early Fathers 1

2 Divine Labour: Contemplation, Energeia, Stress 16

3 Tractarian Mysticism and the Deification of the Soul 33

4 Baptism and Ascent: Created Corruptible, Raised Incorruptible 49

5 Sacramental Typology and Second Nature 63

6 Origen and the Song of Songs 80

7 The Visible and Invisible in Augustine’s Confessions 101

8 Emblems of the Heart 121

9 Love, Spirit, Breath, Fire $\quad 142$

10 The Paradise Within 158

Bibliography 169

Index 177 


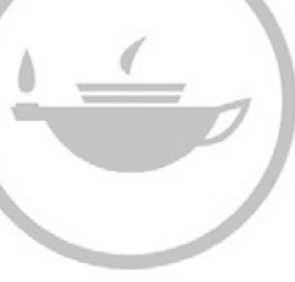

Taylor \& Francis
Taylor \& Francis Group http://taylorandfrancis.com 


\section{Acknowledgments}

All material from the Collected Works of Gerard Manley Hopkins is published by permission of Oxford University Press (OUP). Permission to reproduce journal content from Literature and Theology is granted by OUP Journals. Reproduction of emblem images from The Devout Heart (1634) is by permission of the Provost and Fellows of Eton College. Thanks also to the editor of Victorian Poetry for permission to reproduce an article that first appeared in the journal.

I owe special thanks to Norman Vance for his continuing guidance, encouragement and kindness. To David Jasper, for his helpful comments. To my parents, Elizabeth and Jeevan, for a lifetime of love and support. To my husband and friend Robert Yates who enabled me to pursue this work and whose fine eye and honesty the original thesis benefited from. I am grateful too to the remarkable teachers who have inspired me, in the nearer and more distant past - Con Coroneos, Stephen Heath, Alison Hennegan, Shefali Balsari-Shah, Eunice de Souza, Bubla Basu and Shirin Darasha. This book is dedicated to my mother and my children, Thea and Elias. 


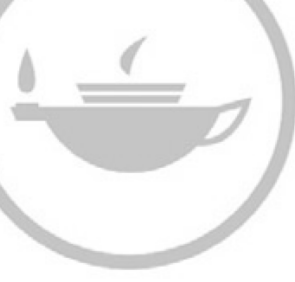

Taylor \& Francis
Taylor \& Francis Group http://taylorandfrancis.com 


\section{1 'Rare-Dear Gerard' Hopkins and the Early Fathers}

There have been in all history a few, a very few men, whom common repute, even where it did not trust them, has treated as having had something happen to them that does not happen to other men, as having seen something, whatever that really was. Plato is the most famous of these... human nature in these men saw something, got a shock; wavers in opinion, looking back, whether there was anything in it or no; but is in a tremble ever since...in Wordsworth when he wrote that ode human nature got another of those shocks, and the tremble from it is spreading. This opinion I do strongly share; I am, ever since I knew the ode, in that tremble. ${ }^{1}$

(23-24 October 1886. Hopkins's own italics)

Hopkins's letter to R. W. Dixon is energetic, dramatic and tending to persuasion. But what remains unsaid here is that Hopkins counts himself amongst those very few men, as one who has 'seen something'. Hopkins's 1876 ode The Wreck of the Deutschland is his testament to this vision. The poem portrays an experience of mystical vision and testifies to the very possibility of such vision, predicated on a faculty of intuitive or mystical knowledge. In this way, Hopkins places himself in that idealist, Platonic tradition which links early Alexandrian theology with Augustinian tradition, finding its most immediate expression in the writings of John Henry Newman. In this tradition, Hopkins finds what will be the centre of his spirituality and poetics, a model of love, knowledge and vision that derives from an ancient religious discourse on contemplation. The practice of contemplation in Alexandrian Christianity is developed from the Platonic theoria, originally understood as the intellectual vision of the truth. For Clement of Alexandria, writing in the second century, contemplation becomes the perfection of gnosis, the 'higher knowledge' of God; it is the soul gazing upon divinity, the direct intuition of the divine described by St Paul in his Hymn to Love: 'We see now through a glass in a dark manner; but then face to face' (1 Cor. 13.12). ${ }^{2}$ Both Clement and the third-century father Origen portray contemplation as the goal of mystical life; the journey of the soul is an ascent to a vision of Christ or God. For Hopkins, as for these 


\section{2 'Rare-Dear Gerard'}

Alexandrian Platonists, the physical world (with the text as its representative) becomes an economy by which the soul ascends to heaven and to the divine vision promised in Matthew 5.9: 'Blessed are the pure in heart, for they shall see God' (KJV).

Why does Hopkins writing in the nineteenth century turn to the contemplative theology of the early church? The answer lies both in his Tractarian roots and in the important figure of Newman. As critics and biographers have pointed out, Hopkins's conversion to Roman Catholicism has frequently obscured his High church background. In his 1991 biography, Robert Martin notes that for almost exactly half his short life, Hopkins was a member of the Church of England. By the time of his conversion at 22 , his intellect and spiritual cast of mind were firmly established. ${ }^{3}$ Hopkins's early Tractarianism turned his attention to patristic tradition. It perhaps also prevented the poet from later aligning himself with that tendency of the Roman church identified by Newman, which in claiming infallible authority, failed to refer to the ancient church as the source of this authority. ${ }^{4}$ For Hopkins, much of the continuity between his Anglican upbringing and Catholic adulthood derives from the patristic and medieval tradition of Christianity revived by the Tractarians. The important influence of Tractarian theology on Hopkins is explored in detail in Chapter 2. This chapter brings to view what is often obscured in studies of the Oxford Movement - its inherent mysticism, as seen in the Tractarian doctrine of the divine indwelling and the sacramental mysticism that issues from this. For Hopkins, after his conversion of 1868 , it is the contemplative teaching of the early church that will enrich and expand his meditative practice as a Jesuit. A number of critics have noted Hopkins's dissatisfaction with the discursive methods of St Ignatius's Spiritual Exercises. This study goes further, suggesting that Hopkins uniquely attempted to unite the meditative practice of the Exercises with the mystical theology of contemplation. Only in this way can Hopkins satisfy the mystical desire of his soul, which, like the psalmist, yearns to 'appear before the face of God' (Ps. 41).

Since the publication of the First Edition of Hopkins's poems in 1918, a few early and influential studies of Hopkins as a Jesuit have suggested his indebtedness to the meditative methods of the Spiritual Exercises. Louis Martz's early study, The Poetry of Meditation (1954), argues the impact of Roman Catholic methods of meditation on English poetry written in the seventeenth century. In his list of meditative writers, Martz includes the Victorian example of Hopkins, suggesting that the poetry of Hopkins together with that of John Donne best shows the imprint of Jesuit methods of meditation. Ignatian meditation is threefold, comprising the practice of composition (or proposing of the subject), analysis and colloquy (when the reformed soul speaks with God). These exercises correspond to the three powers of the soul defined by Augustine, namely memory, understanding and will. Martz suggests that the movement 
of meditative poetry resembles this threefold method; the structure of Ignatian meditation functions as a fundamental organising impulse deep within the poetry. Martz suggests this method as readily apparent in Hopkins, and he draws particular attention to the poet's dramatic 'composition' of scene in the opening lines of many sonnets. Yet, despite the fact that the Ignatian method derives in part from the medieval mystical progression of purgation, illumination and union, Martz remains wary of the appearance of mystical vocabulary in meditative poetry. Although meditative writers frequently use the threefold way of mystics, Martz suggests that their meditations nevertheless end in the realm of devotion and stop short of mystical contemplation.

Another early book to examine Hopkins's work in relation to the Ignatian tradition is David Anthony Downes's Gerard Manley Hopkins: A Study of His Ignatian Spirit (1959). This full-length study closely examines Hopkins's poetry in the light of his Jesuit training. Downes focuses largely on the Ignatian content of Hopkins's verse, except in the final chapter, which develops some of Martz's meditative and structural arguments. The Spiritual Exercises itself comprises four weeks of meditation - the First Week a consideration of sins, the Second Week a meditation on the Life of Christ, the Third Week on the Passion and the Fourth Week a meditation on the Resurrection. Downes traces these themes in Hopkins's work, identifying in the poet a fundamentally Ignatian perspective. He also relates Hopkins's sacramental world view to the principles of Ignatian spirituality laid out in the 'Foundation' of the Exercises. In identifying parallels between the Wreck and the Spiritual Exercises, Downes draws on Hopkins's spiritual notes dating from 1881 to 1883 . These notes were intended by the poet as a treatise on the Exercises, though they remain unfinished. The Wreck itself represents Hopkins's personal experience of the Exercises, and an important theme in Downes's analysis is the operation of grace as understood by the poet through the medium of this devotional manual. Neither Downes nor Martz, however, explore the relevance to Hopkins of the scala mystica from which the Exercises themselves derive. ${ }^{5}$

John Pick in Gerard Manley Hopkins: Priest and Poet (1966) provides a further detailed account of the influence of Ignatian spirituality on Hopkins's life and work. Pick develops many of the arguments made by Downes, similarly suggesting the importance of the 'Principle and Foundation' of the Exercises in Hopkins's thought. The 'Foundation' teaches that human beings are created to praise and glorify the divine, and that all of creation exists to assist in the pursuit of this end. In this way, Hopkins finds in the Exercises a path to God through the created world. Interestingly, Pick is one of the very few critics to note, if in passing, the affinity between the objectives of Ignatius's four weeks of spiritual exercises and the three traditional stages of ascetical life. As the contemplation of sins, the exercises of the First Week may be compared 
with the purgative stage; the Second and Third Weeks, which focus on the life and Passion of Christ, may be seen as analogous with the illuminative stage; the Fourth and last meditation on the Resurrection may be compared with the unitive stage. But Pick also highlights the explicit cautioning against such assumed parallels as given in the Directory, a body of instructions drawn up in the 1590s for teachers or directors of the Spiritual Exercises. ${ }^{6}$ Pick's study itself ultimately denies the reading of Hopkins as a contemplative or mystical poet. Dennis Sobolev, in his article 'Gerard Manley Hopkins and the Language of Mysticism', notes the disappearance of any discussion of Hopkins's mysticism from the 1950s onwards. Sobolev argues that Pick's study, first published in 1942, was influential in ending any tentative speculation on the subject. As Pick unequivocally asserted, 'only by using the word in a very loose and inaccurate sense may Hopkins be called a mystic'.

Overall then, studies of Hopkins's meditative influences have been mainly concerned with the relation of the poet's sacramental vision to the meditative techniques of the Exercises, with a frequent focus on the Ignatian method of harnessing sensory experience for religious understanding. This application of the senses relates to the Ignatian 'composition' of place, the opening meditative exercise Martz first suggested to operate so dramatically in Hopkins's sonnets. As a secondary emphasis, meditative studies of Hopkins have examined the Ignatian content of his poetry; its treatment of the themes of Christ's life, Passion and Resurrection. Yet, none of these studies have significantly shifted critical attention from the techniques and themes of Ignatian meditation to the older contemplative tradition from which they take their origin. Rather, there has been on the whole an attempt to separate the practice of meditation from the mystical realm of contemplation. Yet such a division would be artificial to someone such as Hopkins, with his theological training and his familiarity with patristic tradition. It would have also have been dissatisfying for the poet on account of his 'Platonic impulses', suggested as one reason for Hopkins's attraction to the highly intellectualised Jesuit order. ${ }^{8}$ These impulses likely also explain Hopkins's affinity for the Alexandrian Platonists and the Augustinian tradition, which continues their idealist epistemology.

The threefold method of Ignatian meditation, we noted, is based on Augustine's three powers of the soul. In Augustine's Trinitarian theology, these three powers of memory, understanding and will are assigned to the image of the Trinity in the soul (The Trinity 10.11.18). It is in this way that Augustine understands the individual to be made in the image of God (cf. Gen. 1.27) - the divine image is found not in the body but in the incorporeal soul. The perfect operation of the soul's powers is implicitly understood to perfect the divine image in the soul. Until the sixteenth century, the practice of meditation had an ultimately contemplative end - the mystical knowledge of the inner presence of 
Christ. In his Treatise de Quantitate Animae, Augustine describes seven grades of the soul; the final three stages are tranquillitas, ingressio and contemplatio, and these anticipate the medieval mystical progression of purgation, illumination and union. ${ }^{9}$ Throughout his writings, Augustine propounds an ultimate knowledge or vision of God that is interior to the mind and presented as the perfection of the soul's powers. For Augustine, knowledge is finally remembering; God is sought and found within the mysterious recesses of the mind. Augustine's scala coelis, or ladder to heaven, similarly charts the soul's search for God through the ascending grades of creation. In the final stages, the mind must once again turn inwards in order to find the divine. Ignatian meditation derives from this Augustinian foundation; its discursive emphasis, however, obscures its relation to the medieval scala mystica and to Augustinian theology more broadly. As we will see, Hopkins reads the Exercises in a contemplative light, in a way that challenges contemporary Jesuit practice but is at heart truer to an older Catholic tradition.

An important figure to shape and inform Hopkins's contemplative attitudes is Cardinal Newman. The idealist nature of Newman's belief is apparent, and he is often seen as the modern reincarnation of the true Augustinian spirit. ${ }^{10}$ Also prominent in Newman's thought is the influence of the Alexandrian theologians, particularly Clement and Origen. The Alexandrians were the pre-eminent early proponents of the idealist tradition in orthodox Christian thought and their idealist epistemology is continued and developed in Augustinian tradition. Alexandrian philosophy finds an important place in an early work of Newman's Tractarian phase, Arians of the Fourth Century (1833). In his book, Newman discusses the Tractarian principle of economy that he derives from Clement and Origen. He explores this principle in considerable detail, suggesting two ways in which it may be understood. On the one hand, it is a primarily exegetical technique; in a broader sense, however, the 'economy' comes much closer to the word 'symbol' and is understood as divine action in the world. In his much later Apologia pro Vita Sua (1864), Newman returns to a powerful and moving consideration of the principle of economy and its origin in Alexandrian sacramental mysticism. The Apologia was published when Hopkins was a student at Oxford, and despite an astonishing lack of references to the work in Hopkins's undergraduate records, it is likely he was familiar with it by $1865 .{ }^{11}$ In the Apologia, Newman describes a personal transformation effected through his reading of the Alexandrians. He describes himself as having found in these theologians the 'mystical or sacramental principle', which would so centrally shape his thought.

The battle of Arianism was first fought in Alexandria; Athanasius, the champion of the truth, was Bishop of Alexandria; and in his writings he refers to the great religious names of an earlier date, to 
Origen, Dionysius, and others who were the glory of its see, or of its school. The broad philosophy of Clement and Origen carried me away...Some portions of their teaching, magnificent in themselves, came like music to my inward ear...These were based on the mystical or sacramental principle, and spoke of the various Economies or Dispensations of the Eternal. I understood them to mean that the exterior world, physical and historical, was but the outward manifestation of realities greater than itself. Nature was a parable: Scripture was an allegory......And thus room was made for the anticipation of further and deeper disclosures, of truths still under the veil of the letter, and in their season to be revealed. ${ }^{12}$

The economical or sacramental system described by Newman transfigures the visible world into a parable read by the enlightened. Newman relates this system to that found in Bishop Joseph Butler's Analogy of Religion (1736) and John Keble's The Christian Year (1827). The 'mystical or sacramental principle' effectively implies a simultaneous concealment and revelation; the visible both offers and withholds the invisible, and the seen becomes symbolic of the unseen. Such a system bears out the ultimately mysterious nature of grace and the incapacity of mere reason to fathom divine mysteries. Clement in the Stromateis repeatedly asserts the truth contained within the visible by means of an economy or 'mystery'; gnostic vision is the discernment of this truth. This same mystic idealism is systematised in Origen's conception of the two heavens and two earths. These he understands as sacramentally related; the visible is a blurred imprint of the invisible, showing God as in a glass darkly. For Clement and Origen, the knowledge of Christian revelation in the Incarnation is the key to interpreting the world of matter. This world and all of creation becomes an economy by which the soul ascends to the divine. In other words, such an economical system demands a contemplative ascent; the obscure vision offered by the economy of creation is ultimately paralleled with the perfect vision of God. To be a 'gnostic' of the kind Clement extols, one must practise contemplation, and the Stromateis 7.3.13 gives a representative text relating gnosis and theoria. Here, Clement describes gnostic souls who

keep always moving to higher and yet higher regions, until they no longer greet the divine vision in or by means of mirrors (1 Cor. 12.13), but with loving hearts feast forever on the uncloying, never-ending sight...This is the apprehensive vision of the pure of heart. ${ }^{13}$

(Matt 5.8)

For Origen too, the contemplating mind is the 'divine sense' that sees the invisible; ${ }^{14}$ the 'sheer contemplation' of God is the end goal of religious life and human aspiration. ${ }^{15}$ In the writings of both Alexandrians, 
contemplation is aligned with both earth and heaven, present and future. The activity of contemplation is the means by which the soul ascends and the end goal of this ascent. Naturally, there are differences too in the contemplative theology propounded by the two fathers. ${ }^{16}$ What is clear, however, is that the highest spiritual development is seen in the exercise of contemplation, and this contemplative faculty is the soul's highest correspondence with a sacramental or economical creation.

A number of critics have noted the importance of the Tractarian principle of economy for Hopkins. Yet, this has been viewed in a primarily formal sense, in relation to Hopkins's use of the multiple meanings associated with typology. The economical system in this sense is connected with Tractarian poetics - the typological principles seen in Keble's Christian Year or in the poetry of Newman himself. Such an application of the principle has not, however, looked to its origins in patristic theology. In Clement and Origen, the system of economies is emphatically given meaning by the discourse on contemplation that accompanies it. Hopkins's poetry and prose must also be read in relation to this discourse. Contemplative theology is at the centre of Hopkins's theopoetics and has yet been neglected in discussions of his Tractarian poetics. George Landow, for example, argues for a typological reading of Hopkins. In his important book Victorian Types, Victorian Shadows, he suggests that much of what is difficult in Hopkins can be explained in relation to the poet's application of a typological or economical system. At the same time, Landow asserts that this principle provides a better explanation of Hopkins's verse than the tradition of gnosticism (he refers here to James Cotter's study, Inscape: The Christology and Poetry of G. M. Hopkins, which argues the gnostic tradition as key to a reading of Hopkins). Yet, the economical principle and the tradition of gnosticism are intimately related, as Hopkins would have known from Newman and from his own reading of the fathers. The mystical or sacramental principle elicits and is accompanied by the activity of contemplation. As the higher activity of the soul, this practice of contemplation is central to gnosticism; for the Alexandrians, the spiritual faculty that reads or contemplates the mysteries of this world, may also attain to an intuitive apprehension of the divine. ${ }^{17}$

Hopkins's poetry undoubtedly makes extensive use of typological and economical representation. But it is important to appreciate that in Hopkins's poetics, as in patristic exegesis, the typological supports the mystical. Hopkins finds in Newman and the Alexandrians not only a sacramental method, but a broader contemplative theology. Newman's development of Alexandrian idealism plays a key mediating role here. As Harold Weatherby notes, Newman's conception of two systems, one physical and one moral, is clearly indebted to Origen's idea of the relation between the visible and invisible worlds. ${ }^{18}$ This Origenian idea strongly appealed to Newman. Indeed, that this enthusiasm for Origen serves as 
common ground between Hopkins and Newman is an intriguing point neglected by scholars and one that merits closer attention. Interestingly, the sole recorded reference to Origen in Hopkins's writings is found in a letter written in the year that followed the publication of Newman's Apologia. In a letter dated Epiphany, January 6, 1865, Hopkins declares Savonarola to be 'the only person in history (except perhaps Origen) about whom I have a real feeling. ${ }^{19}$ Hopkins's effusive affirmation is similar to Newman's emotive accounts of Origen in the Apologia, where Newman declares that he 'loves the name' of Origen. Origen's economical system receives its fullest exposition in his Commentary on the Song of Songs. The erotic imagery of the Song, if read literally, can lead to error; but contemplated by the spiritual sense, an understanding of the Song raises the soul to a knowledge of divine and heavenly mysteries. Origen's Commentary on the Song is woven into the mystical, interior narrative of Hopkins's Wreck of the Deutschland. As a veiled account of the soul's ascent to the divine, Hopkins's ode owes much to Origen's threefold exegetical system, as we will see in Chapter 6 .

The principle of economy is suited not only to the subject matter of The Wreck of the Deutschland, but also to Hopkins's vocation and temperament. Commenting in later years on the histories of earlier members of the Society of Jesus, Hopkins writes to Dixon: 'I quote these cases to prove that shew and brilliancy do not suit us, that we cultivate the commonplace outwardly and wish the beauty of the king's daughter the soul to be from within.' (1 December 1881$)^{20}$ The dangers of pride, fame and the temptations of art found the young Hopkins caught between the conflicting pulls of poetry and priesthood. He famously destroyed his early experiments in verse, and, consequently, the Wreck was written after years of artistic abstinence. In his ode, Hopkins takes refuge in a typological language of shadows and similitudes - not an ostentatious or flamboyant style, but one that (for the most part) 'cultivate[s] the common-place outwardly'. The gravity of the subject matter demands a great measure of religious reserve. Only in the obscurity of an economical system is Hopkins able to reconcile the paradoxical demands of art, as it strives for expression, and a mysticism that reaches towards silence. The Wreck of the Deutschland becomes an unparalleled exercise in economy, accommodating the needs of both poet and reader. As Newman observes, economy, in the interpretation of scripture, is the principle of 'accommodation to the feelings and prejudices of the hearer, in leading him to the reception of a novel or unacceptable doctrine'. ${ }^{21}$ In the Victorian times in which Hopkins lived and wrote, contemplation was a dangerous activity, unattainable and undesirable for ordinary Christians. To lead his readers to the vision of God centrally inscribed within his ode, Hopkins must write the poem as sacrament or mystery. To do so, he uses a typological and allegorical language, inscribing multiple levels of meaning. Each level leads to a deeper or more elevated apprehension of 
the truth - yet a truth that never ceases to be a mystery. Hopkins's text must be contemplated as Hopkins contemplated the world, ascending from the visible to the invisible, from the corporeal to the divine. Like Newman, Hopkins derives from Origen and patristic tradition a sacramental and mystical system whose culmination is the highest love, vision or knowledge to which the mind or heart can attain - the divine vision.

The immediate knowledge or vision of God is an idea at the centre of Newman's Grammar of Assent (1870). In his earlier Apologia, Newman had given a personal testimony of the direct relationship between the soul and a luminous mental image of God, experienced without mediation of the intellect. Newman's Grammar is again centrally concerned with this intuitive apprehension of God as the sustaining principle of faith. Newman writes: 'what I am directly aiming at, is to explain how we gain an image of God and give a real assent to the proposition that He exists. ${ }^{22}$ For Newman, a real faith can only be one that is based on an immediate knowledge of the object of faith, and not on mere abstractions or 'notions'. ${ }^{23}$ Faith must be based on real assent, and Newman develops his argument through an important set of interrelated terms. Real assent is to 'things or images' and brings immediate intuitive awareness; it is aligned with implicit reason. Notional assent is to conclusions and abstractions and is aligned with explicit reason. Newman's implicit reason (analogous to Coleridge's 'philosophic imagination') is the higher faculty, able to apprehend God in 'a complex act of intuition'. It is this intuitive and immediate knowledge of God that Newman suggests to be at the heart of religion. Only the image of God can sustain the soul, not mere reason or abstraction. For Newman, the image of God is imprinted directly upon the conscience, which alone can achieve a real apprehension of God. It is in Newman's development of his idea of the conscience that his Platonic idealism becomes apparent. The image of God imprinted on the conscience is not knowledge acquired through the senses in a Thomist sense, but is instead akin to a Platonic doctrine of innate ideas or to Augustine's conception of infused grace (for Aquinas, Newman's real assent or real apprehension would be possible only in heaven). ${ }^{24}$

Newman's argument for the image of God intuitively apprehended as the ground of faith continues the idea of contemplation developed in Alexandrian theology. At the same time, Newman's conception of 'real apprehension' modifies Alexandrian teaching, bringing to bear contemporary Romantic attitudes. The change lies in an 'affective' modification of traditional neo-Platonic idealism, a modification seen also in Coleridge (who, however, derives his idealism from Plotinus). For Clement and Origen, it is the mind enlightened by Christian doctrine and instructed in the discipline of contemplation that is the primary faculty for the intuitive apprehension of God. For Newman, neither the mind nor affections in themselves but the conscience as the union of these faculties 
becomes the medium by which divine images and ideas are imprinted in the soul. Contemplation for Newman is not a purely intellectual activity, but one that is involved as much with feeling as with cognition. In this, he is in keeping with the contemporary merging of idealism and sensationalism that had followed from Wordsworth and Coleridge. In both these Romantic poets, traditional Neo-Platonism and idealist conceptions of intuition and illumination merge with eighteenth-century theories of sensation; their poetry seeks to affirm the spiritual without denying the affections or the experience of the senses. ${ }^{25}$ Similarly, for Newman, real apprehension is the achievement not only of mind and memory, but also of the passions and the imagination. In the Grammar of Assent, it is the conscience, the intellect in conjunction with the imagination and the affections, that becomes the locus of a mental image of God.

The Wreck of the Deutschland inaugurates a moment of assent. 'I did say yes', Hopkins writes in the opening section of the poem. This moment of assent, we will see, is accompanied by an intuitive or mystical apprehension of God that has important connections with Newman's Grammar and with patristic and contemplative theology more broadly. Few critics see Hopkins as a mystic, although Alison Sulloway observes that Hopkins, writing to Bridges, hints that Christ appeared to him at one time or another. ${ }^{26}$ Yet, The Wreck of the Deutschland is at its centre a poem about seeing God. A complex narrative of faith and conversion, Hopkins's poem conceals an inner narrative that follows Newman's Grammar in celebrating the mystical presence of God and the intuitive apprehension of his image. Curiously, Hopkins began reading the Grammar of Assent in August 1873, only two and a half years before he began work on the Wreck. The abiding influence of Newman's philosophical opus on Hopkins may be gauged by his request to Newman in February 1883 to publish a sixth edition of the book with a commentary. When declined, the request was made again, two months later. Newman's Grammar may be seen to provide Hopkins with a contemplative framework with which he is able to extend the meditative discourse of the Exercises. That the two works are linked in Hopkins's spiritual imagination is perhaps intimated in a coincidence of timing. As noted, Hopkins's unfinished writings on the Exercises span from 1881 to 1883. Much of this writing was done during a Long Retreat of NovemberDecember 1881. But the creative year, Christopher Devlin suggests, was 1881-1882. ${ }^{27}$ Hopkins's request to Newman to write a commentary on the Grammar, at the beginning of 1883, follows very shortly on the heels of his incomplete treatise on the Exercises. Hopkins's affective, contemplative modifications of Ignatian meditation indeed bear much affinity to Newman's conception of the conscience as the organ of divine intuition; for Hopkins, Newman's contemplative insights as based on patristic theology offer a remedy for the purely speculative and discursive emphasis of Ignatian meditation. 
A number of critics including Downes and, more recently, Jude Nixon and Margaret Johnson, have noted Hopkins's familiarity with Newman's arguments for the role of intuition and the affections in matters of faith. Downes points to Hopkins's letters to his father at the time of his conversion, noting that Hopkins's entire argument and explanation of his decision suggest that he clearly understood 'the workings of Newman's illative imagination'. ${ }^{28}$ Johnson similarly points to Hopkins's discussion of his conversion in a letter to Liddon, observing that Hopkins uses categories that closely approximate Newman's distinctions between real and notional assent, faith and reason. ${ }^{29}$ Newman's 'illative sense' is virtually interchangeable with 'implicit reason'; both are the grounds of real assent. But these readings do not relate Newman's idealist epistemology to the contemplative discourse of Alexandrian theology. In fact, Newman's 'conscience' can be understood as a substitution for the Alexandrian conception of 'gnosis. ${ }^{30}$ Deriving from the gnostic and contemplative tradition of Clement and Origen, Newman's 'conscience' is similarly concerned with a mystical apprehension or intuition of the imago Dei. No doubt this 'image' plays on the central paradox of contemplative discourse: to contemplate God is to see the unseen. But it is precisely Newman's formulation of the intuitive apprehension of the divine that becomes the centre of Hopkins's enigmatic Wreck of the Deutschland. This is Hopkins's paradise within: the image of the divine in the soul, not only known through Christian doctrine, but also felt and contemplated through the ultimately mystical faculty by which belief is born.

Hopkins in his powerful account of the idea of vision in Plato and Wordsworth describes the men who had 'seen something, whatever that something really was'. Hopkins's relation of Wordsworth and Plato points to the very yoking of spiritual intuition and affective experience that is the Romantic modification of Neo-Platonic tradition. Perhaps Hopkins has something of this in mind when he declares the 'shock' of Wordsworth's Intimations of Immortality. Hopkins recognised too that Newman drew on this Romantic inheritance, and in a letter dated December 1, 1881, he describes the poetry of Keble, Faber and Newman as the expiration of the Lake School. ${ }^{31}$ As Nixon observes, Hopkins is probably the first critic to read the Tractarians as Romantics. ${ }^{32}$ The Wreck of the Deutschland offers a further insight into this relation and suggests Hopkins's recognition of the fact that Newman's illative sense and his argument for the intuitive apprehension of God had much to do with a Romantic epistemology.

But how shall I ... make me room there:

Reach me a ... Fancy, come faster-

Strike you the sight of it? look at it loom there, 
Thing that she ... there then! the Master, Ipse, the only one, Christ, King, Head...

Ah! there was a heart right!

There was single eye!

Read the unshapeable shock night

And knew the who and the why;

Wording it how but by him that present and past,

Heaven and earth are word of, worded by?-

This passage functions as a key semantic nexus in Hopkins's complex synthesis of typological and allegorical meaning. Hopkins inscribes here a mystical vision, and the odd use of the word 'Fancy' can in part be explained by Newman's real apprehension. Real assent, as Newman describes it, is a response to 'things or images'. Belief, which is synonymous with real assent, apprehends the object of faith in an act of intuition - a vision brought about by the imagination and affections. At this enigmatic climax of the Wreck, Hopkins jarringly describes a vision of a 'thing'. In some respects, this is the Kantian thing-in-itself, but Hopkins's language also echoes Newman's Grammar of Assent. This 'thing' is itself the divine image, apprehended as an object of contemplation. Hopkins critically links this vision with the operation of 'Fancy', calling up those famous Romantic categories of Fancy and Imagination. Coleridge's categories of these two faculties show a close kinship with Newman's argument for the role of the imagination and affections in religious belief. Coleridge was an important influence on Newman's conception of conscience, and Hopkins's use of the term 'Fancy' effectively calls up a whole Romantic epistemology - an appeal to the imagination, the passions and the heart. For Newman, conscience and heart are closely related. In his Grammar of Assent, Newman argues for an intuitive knowledge of God 'in my conscience and heart'; the two are effectively equated too in Newman's description of God as seen by a 'right heart [my italics] ${ }^{33}$ Hopkins similarly suggests this divine vision as the achievement of a 'heart right' (29). The passage is a central moment in Hopkins's theopoetics. It is his testimony to a vision seen through a faculty akin to Coleridge's philosophic imagination and to Newman's conscience. Even the word 'shock' (29) suggests a sudden 'impression on the mind', an intuitive act of apprehension; notably, it is the same word Hopkins uses when describing the 'shock' of reading Wordsworth's Intimations, the poetic legacy of a man who has 'seen something'.

It could be argued of course that Hopkins's use of the word 'Fancy' places him on the wrong side of Coleridge's philosophic distinction. For Coleridge, fancy is the lower power and imagination the higher. 
Fancy is a mere aggregating faculty of mind; imagination is the modifying and co-adunating faculty (more closely akin to Newman's 'conscience'). However, Coleridge also uses the terms interchangeably, and what is most important is that both terms denote the mental faculty opposed to reason and implicitly aligned with Newman's affective understanding of the conscience. Indeed, Fancy is linked by Coleridge to 'images' and 'impressions', and Hopkins's use of the word intimates (as does the stanza taken as a whole) that metaphor of seeing, which lies at the heart of contemplative discourse. Ultimately, 'Fancy' in The Wreck of the Deutschland functions largely as a literary cue, intimating a nonreasoning faculty or illative sense, which alone can apprehend the divine. Newman's conception of conscience, as we have seen, draws on the Alexandrian idea of gnosis as linked with contemplative practice. Where Clement speaks of the 'true gnostic', Origen speaks of the 'spiritual' or 'perfect' Christian who possesses a real and 'visual' knowledge of Christ (this is the union with God suggested in 1 John 3.2: 'now are we the sons of God...when he shall appear, we shall be like him; for we shall see him as he is', KJV). ${ }^{34}$ Through the Grammar of Assent, Hopkins reaches back to a patristic theology of contemplation. But, as for Newman and Augustine, it is no longer a purely intellectual model of contemplative ascent. Hopkins's 'heart', like Newman's conscience, participates in that affective modification of neo-Platonic tradition that is the achievement of Newman and the Romantics before him. At the heart of the Wreck is a powerful affirmation of personal belief and an intuitive apprehension of the divine, which alone can be the grounds of such assent.

\section{Notes}

1 G. M. Hopkins, The Collected Works of Gerard Manley Hopkins, vol. 2 Correspondence 1882-1889, ed. R. K. R. Thornton and C. Philips (London: OUP, 2013), 821. All material from this title is published by permission of Oxford University Press.

2 Perfect contemplation is naturally reserved for the blessed in heaven, but patristic discourse on contemplation importantly suggests that the vision of God may be glimpsed even during mortal life; see Bernard McGinn, The Foundations of Mysticism, vol. 1 The Presence of God: A History of Western Christian Mysticism (New York: Crossroad, 1991), 71-72. Unless otherwise specified all biblical citations are to the Douay-Rheims Bible. Following his reception into the Jesuit order in 1868, Hopkins would have been expected to consult the Latin Vulgate, or the Douay-Rheims English translation, with its emphasis on the Latin. Naturally, Hopkins would also be entirely familiar with the 1611 King James Version of his Protestant youth, and the Greek New Testament of his classical training.

3 Robert Bernard Martin, Gerard Manley Hopkins: A Very Private Life (New York: G. P. Putnam's Sons, 1991), xv.

4 This is the subject of Lecture 2 of Newman's Lectures on the Prophetical Office of the Church, entitled 'On the Roman Teaching as Neglectful of Antiquity'. Here Newman writes, 'They profess to appeal to primitive 
Christianity...Whatever principles they profess in theory...yet when they come to particulars...they supersede the appeal to Scripture and Antiquity by putting forward the infallibility of the Church...', Lecture 2.1, www. newmanreader.org/works/viamedia/volume1/lecture2.html.

5 Louis Martz points out that meditative treatises of the seventeenth century did not in general make explicit the underlying theology of the three powers of the soul as analogous to the Trinity; these theological implications were either seen as too theoretical to be discussed in meditative treatises, or knowledge of these implications was assumed on the part of the reader. See Louis L. Martz, The Poetry of Meditation, rev. ed. (1954; repr., New Haven, CT: Yale University Press, 1962), 34.

6 John Pick, Gerard Manley Hopkins: Priest and Poet, 2nd ed. (London: OUP, 1966), 28. This injunction perhaps goes some way toward explaining why Hopkins might choose to submerge the operation of this threefold mystical structure in his own work. Hopkins's use of this structure of ascent is seen in his incorporation of meditative emblems as discussed in Chapter 7.

7 Pick, Gerard Manley Hopkins, 131, quoted in Dennis Sobolev, 'Gerard Manley Hopkins and the Language of Mysticism,' Conference on Christianity and Literature (22 June 2004), www.encyclopedia.com/doc/1G1-125407680. html. Sobolev refers to the 1942 edition of Pick's study.

8 This observation is made by David Downes, cited in Jude V. Nixon, Gerard Manley Hopkins and His Contemporaries: Liddon, Newman, Darwin and Pater (New York: Garland Publishing, Inc., 1994), 104.

9 For a fuller discussion of this, see Dom Cuthbert Butler, Western Mysticism: Augustine, Gregory, and Bernard on Contemplation and the Contemplative Life, 3rd ed. (London: Constable \& Co Ltd, 1967), 28.

10 It is Eric Przywara who suggests Newman as a reincarnation of Augustine; Przywara is cited by Harold Weatherby in Cardinal Newman in His Age: His Place in English Theology and Literature (Nashville, TN: Vanderbilt University Press, 1973), 71. My discussion of the influence of Newman's idealism on Hopkins is indebted to Weatherby's insightful reading of Newman.

11 Alison Sulloway is the first to observe that Hopkins's 1865 eucharistic poem has for its title a phrase used in the Apologia - 'The Half-way House'; see Alison Sulloway, Gerard Manley Hopkins and the Victorian Temper (London: Routledge, 1972), 18.

12 John Henry Newman, Apologia Pro Vita Sua \& 6 Sermons, ed. F. Turner (New Haven: Yale University Press, 2008), 154-55.

13 McGinn, The Foundations of Mysticism, 105.

14 A. N. Williams, The Divine Sense: The Intellect in Patristic Theology (Cambridge: CUP, 2007), 82.

15 Ibid., 81.

16 Clement's conception of contemplation is in many respects less rarefied than Origen's; see Williams, The Divine Sense, 81.

17 The importance of an Augustinian-Origenian view of exegesis within Hopkins's poetry is also suggested by Jeffrey Loomis in his study of Hopkins's sacramental poetics. However, Loomis seems not to engage with the contemplative discourse that is traditionally allied with such a system.

18 Weatherby, Cardinal Newman, 95.

19 G. M. Hopkins, Collected Works, vol. 1 Correspondence 1852-1881, ed. R. K. R. Thornton and C. Philips (London: OUP, 1938), 78. All material from this title is published by permission of Oxford University Press.

20 Hopkins, Collected Works, vol. 1 Correspondence, 504. This letter of December 1881 is the very one in which Hopkins reflects on the 'obscure' but 
'brilliant' Polish Jesuit, whose little emblem book on the life of St Stanislaus is 'much in the style of Herbert and his school', ibid., 503. Emblematic imagery is one of the primary means by which Hopkins builds his interior narrative in the Wreck; see Chapter 8.

21 Newman, The Arians of the Fourth Century, quoted in Weatherby, Cardinal Newman, 84.

22 John Henry Newman, An Essay in Aid of a Grammar of Assent, ed. I. T. Ker (Oxford: Clarendon Press, 1985), 73.

23 Newman for the most speaks of the notional as abstractions from the visible or sensible.

24 Weatherby, Cardinal Newman, 159.

25 Weatherby here refers to the work of Claude Finney on the Neo-Platonic tradition in English poetry; Weatherby, Cardinal Newman, 110, 137.

26 Sulloway, Gerard Manley Hopkins and the Victorian Temper, 184.

27 G. M. Hopkins, The Sermons and Devotional Writings of Gerard Manley Hopkins, ed. S. J. Christopher Devlin (London: OUP, 1959), 107. All material from this title is published by permission of Oxford University Press.

28 Nixon, Gerard Manley Hopkins and His Contemporaries, 103.

29 Margaret Johnson, Gerard Manley Hopkins and Tractarian Poetry (Aldershot: Ashgate, 1997), 169.

30 Weatherby, Cardinal Newman, 107.

31 Hopkins, Collected Works, vol. 1 Correspondence, 506.

32 Nixon, Gerard Manley Hopkins and His Contemporaries, 87.

33 Weatherby, Cardinal Newman, 162.

34 McGinn, The Foundations of Mysticism, 124. 